\title{
Gençler Arası Şiddetin Nedenlerini Belirlemeye Yönelik Alan Çalışması Elazı̆̆ İli Örneği
}

\section{Elazı̆̆ Province Case Study On Determining The Reasons Of Violence Among Teens}

\author{
Yeşim Kubar ${ }^{a^{*}}$ \\ ${ }^{a}$ Dr. Öğr. Üyesi, Fırat Üniversitesi, İktisadi ve İdari Bilimler Fakültesi, İktisat Bölümü, 23190, Elazığ/Türkiye \\ ORCID:0000-0002-3439-9430
}

\section{MAKALE BİLGİSİ \\ Makale Geçmişi: \\ Başvuru tarihi: 14 Ekim 2018 \\ Düzeltme tarihi: 26 Aralık 2018 \\ Kabul tarihi: 17 Ocak 2019}

\section{Anahtar Kelimeler:}

Şiddet

Şiddet Türleri

Ekonomik Şiddet

Genç Şiddeti

\section{A R T I CLE INFO}

\section{Article history:}

Received 14 October 2018

Received in revised form 26 December 2018

Accepted 17 January 2019

\section{Keywords:}

Violence

Sort of Violence

Economic Violence

Young Violence
ÖZ

Günümüzde de genç ve ergen gruplarında artan şiddet olgusu dikkat çekmektedir. Şiddete yönelten faktörler kişilik özellikleri, ailevi özellikler ve okul ortamına ait özellikler olarak sınıflandırılmaktadır. Şiddet türlerine eğilimi etkileyen sebeplerin tespit edilmesi ve bu nedenlerin özel ve devlet okullarında farklılık gösterip göstermediğinin ortaya çıkarılması bu çalışmanın amacını teşkil etmektedir. Çalışma Elazığ ili merkez ilçeye bağlı olan devlet ve özel liselerde gerçekleştirilmiş 42 liseye anket uygulaması yapılarak tamamlanmıştır. Çalışmada; lise öğrencilerinin çoğunun yaşamlarında şiddetin var olduğu ve bunu sıklıkla arkadaş ve okul ortamında yaşadıkları, şiddeti daha çok "dayak ve kavga" gibi fiziksel boyutuyla tanımladıkları, cinsiyetin, sınıfın, özellikle babanın ve annenin işsiz olmasının, ekonomik durumun, gelir seviyesinin şiddet eğiliminde etkili faktörler olduğu sonucuna ulaşılmıştır.

\section{A B S T R ACT}

Today, the phenomenon violence increasing in the young and adolescent ages attracts attention. The factors directing to violence are classified as personality traits, familial characteristics, and characteristics belonging to school environment. The aim of this study is to identify the causes affecting the tendency to the sort of violence and reveal whether or not these causes becomes different in the private and public schools. The study was carried out in the public and private high schools under the central district of the province Elâzlğ and completed by administering survey in 42 high schools. In the study, it was concluded that there was violence in the lives of most of high school student; that they experienced this in the classmate and school environments; that they defined violence in its physical dimensions such as "beating and fighting"; that the gender, class, especially the mother and father that are unemployed, economic state, and income level were the effective factors on propensity for violence.

\section{Giriş}

Geçmişten günümüze kadar varlığını sürdüren, teknolojinin kullanımıyla birlikte farklı şekillerde yaşanmaya devam eden önemli konulardan biri şiddet olgusudur. Şiddet insan haklarına yönelik ciddi bir tehdittir ve çözülmesi zorunlu olarak 21. yüzyılın gelişmiş ve gelişmekte olan ülkelerinde, insanların toplumsal sorunlarından biri olarak varlığını sürdürmektedir (http://nces.ed.gov/pubsearch).

Şiddet olayının açığa çıkmasının birçok nedenin vardır bu yüzden şiddet, biyo-psiko-sosyal bütünlük içinde ele alınmaktadır. Dünya çapında 49 toplum üzerinde yürütülen bir araştırmada, sosyal şiddet ve anti-sosyal davranışın ortak bir tablosu oluşturulmaya çalışılmış araştırmacılar, şiddeti

\footnotetext{
* Sorumlu yazar/Corresponding author

e-posta: ykubar@firat.edu.tr
} 
yaratan unsurları ferdi gelir eşitsizliği, siyasi şiddet, bolluk, sosyal hareketlilik, sosyo - kültürel heterojenlik, sosyal değişme oranı ve nüfus büyüklüğü olarak ifade etmişlerdir (Özerkmen, 2012:8). Şiddet farklı özelikler dikkate alınarak farklı şekillerde sınıflandırılmaktadır:

Fiziksel Şiddet: itmek, tokat atmak, tekmelemek, yumruklamak, kol-bacak kırmak, saçından sürüklemek, temel ihtiyaçları kısıtlamak, yaralamak vb. etkileşimler olarak tanımlanmaktadir.

Sözlü Şiddet: sürekli eleştirmek, aşağılamak, küfür, tehdit, katılımı engellemek, sorgulamak, bağırmak, lakap takmak, alay etmek, hakaret, küçümsemek vb. davranışlar olarak tanımlanmaktadır

Duygusal Şiddet: gruptan dişlama, küçük düşürme, ayrımcılık yapma, eşyaya zarar verme olarak tanımlanmaktadır.

Ekonomik Şiddet: parasını almak ve geri vermemek, istemediği işte çalıştırmak, çalıştırmamak, işe yollamamak veya zorla çalıştırmak, eline hiç para vermemek vb uygulamalar olarak tanımlanmaktadır.

Cinsel Şiddet: ilişkiye zorlamak, tecavüz, başka kişilerle cinsel ilişkiye zorlamak, kadınlığın/erkekliğini aşağılamak, taciz, namus ve töre baskısı vb. olarak tanımlanmaktadır (Birimoğlu, 2012: 14-15).

Psikopatoloji Kuramı (Aile İçi Şiddete Kuramsal Bakış): Şiddet uygulayan kişilerin \%60-72 sinde alkol ve madde kötüye kullanımı gözlenirken, \%85 inde antisosyal, edilgensaldırganparanoid kişilik özellikleri, öfke denetiminde sorunlar, dürtü denetim bozuklukları gözlenmektedir. Ailesinde tekrarlı bir şekilde şiddet gören kişilerde depresyona daha fazla rastlanmaktadır. Şiddet davranışı sonucunda öfkenin bir şekilde bastırılması ile ortaya çıkan depresyon, bu kişilerde impulsif suisid girişimine neden olmaktadır

(www.Aic.Gov.Au/Publications/Proceedings/27/Roberts.P df) .

Sosyal Öğrenme Kuramı-Şiddetin Aktarlması: Şiddet sorununun önemli noktalarından biri, kuşaktan kuşağa aktarılmasıdır. Şiddet uygulayan yetişkinlerin büyük bölümünde çocuklukta aile içi şiddete maruz kalma öyküsü saptanmaktadır. İçselleştirilen öfke, korku ve çökkünlük duyguları, kişinin tutum ve davranışlarını yaşam boyu etkileyebilmektedir. Şiddet ve ihmal sonucu oluşan intrapsişik yapı, çoğu kez yine çeşitli biçimleriyle şiddeti doğuran bir saldırganlık kaynağı olmaktadır (Vahip, 2002: 302-306). Çocukta şiddet davranışının ilk belirtileri umursamazlık şeklinde kendini göstermekte, çocuk arkadaşına, kardeşine, hayvanlara karşı zalimce davranabilmekte ama sonuçlarından dolayı acı çekmemektedir. Gençlik ve ergenlik döneminde davranışlarına sınırlandırma getirildiğinde şiddet davranışının uygulayıcısı haline dönüşebilmektedir. Aile içerisinde erkek çocuk gördüğü ve öğrendiği şiddeti ileride eşine veya çocuklarına uygulamaya yatkın olmakta, kız çocukları baba evinde gördüğü ve içselleştirdiği şiddeti, eşinden gördüğünde olağan karşılamaktadır (Chase vd.,2001: 567-572).

Kültür Kuramı: 21. yüzyılda şiddetin evrenselliği ve yaygınlığı, ürkütücü boyutlara ulaşmıştır. Aile içinde başlayan şiddet, modern toplumlarda iktisadi sistemlerin etkisiyle topluma yayılıp meşrulaşmakta; kadınlara ve çocuklara yönelik kötü ve şiddet içerikli uygulamalar, geleneksel kültürün öğeleri olarak sürdürülmektedir. Dünya çapında yapılan çalışmalarla kadına karşı şiddetin cinsiyet rollerinin katı bir şekilde tanımlandığı ve bunun için baskının yapıldığı, erkekliğin; sertlik, egemen olma ile bağdaştırıldığı yerlerde en yaygın şekilde görüldüğü belirlenmiştir. Aile içi ilişkiler düzeyinde kültürler arası çalışmalar, aile içinde servetin ve karar verme yetkisinin erkeğin kontrolünde olmasının ve eşler arasındaki uyuşmazlığın, istismarın kuvvetli bir nedeni olduğunu göstermiştir (www.Apa.Org/Books/431639a.Html - 7k).

Şiddet farklı şekillerde tanımlanıp farklı türlere ayrıldığı gibi, farklı kültürlerde de farklı anlamlar içerebilmektedir. Doğu ya da Batı kültürlerinde şiddetin kullanılma maksadından, yöntem ve çeşidine kadar pek çok farklılık görülebilmektedir (Çakır, 2007: 22). Şiddetin insan hayatın da kaybettirdikleri düşünüldüğünde, gerekli önlemlerin alınması gündemi meşgul eden konuların başında gelmektedir. Şiddet için alınan önlemler etkili olursa, şiddetin görülme sıklığında kendiliğinden azalma olacağı bu nedenle, toplumu bilinçlendirme, seminerler düzenleme ve eğitim kalitesinin yükseltilmesinin gerekli olduğu düşünülmektedir.

Evlerde, sokakta, futbol sahalarında yaşanan şiddet olaylarının son zamanlarda okullarda da yaşanıyor olması dikkat çekicidir. Medyada, okullarda yaşanan şiddet olaylarına ilişkin haberlerin yer alması çocuk ve ergenler arasında şiddet içeren olayların artması, şiddetin nereden kaynaklandığını anlama, meydana geldiğinde şiddeti azaltacak ve önleyecek yapıcı yollar bulma konusunda yapılan çalışmaları artırmaktadır. Ergenlik döneminde, bireyler arasında çatışma doğuracak birçok yeni sorumluluk ve kimlik oluşturma gereksinimi ortaya çıkmaktadır. Ortaya çıkan çatışmalar hem içsel hem de toplumla yaşanmakta, genç bireyler arasında topluma karşı bir başkaldırış olarak ortaya çıkmaktadır. Gençlik dönemi, risk alma davranışının en çok yaşandığı dönem olarak kabul edilmektedir (Gelbal,2006;28-31). Ergenlik döneminde bireyler, kendilerini önemsiz hissedebilmekte, şiddet ile yaşamını olumsuz kılan her şeyi yok edebileceğine inanarak sorunlar karşısında şiddeti kullanabilmektedirler. Gençleri şiddete yönelten önemli etkenlerden biri de gençlerin aileleridir. Aile içinde şiddetin yaygın olarak görülmesi, ailenin sosyoekonomik durumu, yaşanılan sosyal çevre, gençleri şiddete yöneltmektedir (Deveci ve ark., 2007). Şiddet davranışı gösteren gençlerin aile içi ilişkilerinde roller, iletişim, duygusal tepki verebilme, davranış kontrolü, gereken ilgiyi gösterebilme gibi konularda sorunlar yaşandığ gözlenmektedir (Avcı ve Güçray, 2010). Çocukların, gençlerin, kadınların ve erkeklerin şiddetten korunması özel bir önem taşımaktadır. Bu gruplar arasında çocuklar ve gençler için okulların, sosyal yaşam alanlarında karşılaştıkları şiddetin etkilerini azaltabilecek özellikleri barındırması beklenmekte ancak bazen şiddet kaynağı da olabilmektedirler. Okulda şiddet, olarak adlandırılan şiddetin bu biçimi, duygusal, sözel, fiziksel, cinsel, ekonomik vb. gibi tüm şiddet türlerini içerebilmektedir.

Gençlik gibi, insanın dinamik, korkusuz, verimli döneminin incelenmesi, enerjik yapısından yararlanılması insanlık için oldukça önemlidir. Gençlik, bütün sosyolojik kurumların; 
eğitim, aile, din, ekonomi, siyaset üzerinde durduğu ve ilgi alanı oluşturduğu varlık ölçeğidir. Gençlik dönemi, nüfus hareketleri içinde demografik açıdan oluşan göç vb. sorunların içine çekilerek, sıra dışı ve yasadışı sektörlerin etkisinin arttığı bir dönemdir ( Filiz, 2000: 117). Bu nedenle, orta öğretim öğrencilerinin çevresi ve gittiği okullar itibariyle çeşitli ideolojilerle şartlandırılması mümkündür (Yarman, 2000:137).

Gençlerin ruhsal açıdan toplumsallaşma süreci dışında kalması, yüksek idealler yerine, insanlara karışmaktan hoşlanmayan, çaresizlik içindeki psikolojik-ruhsal yapılarıyla; kırıcılık, agresiflik, şiddet ve vahşet gibi örüntüler geliştirmesine neden olmakta siyasal ve sosyal entegrasyon, patolojik mantık kurgularıyla çağın hastalığı olarak ifade edilmektedir. Çağımızın bu hastalığı, siyasal yabancılaşma psikolojik, yalnızlaşma ve sosyolojik şiddet örüntülerini içermektedir. $\mathrm{Bu}$ paradigmalardan bakıldığında; Türkiye'de Gençlik sorunlarının analizi büyük bir önem taşımaktadır (Tuncay, 2000: 234).

Kitle iletişim araçlarının yaygınlaşması ile "küresel kültür", bireyin yaşamını bir bütün olarak etkilemektedir. Bu etki ekonomik, siyasi, sosyal, kültürel ve ahlaki alanda da kendini göstermektedir. 20. yüzyılın ikinci yarısından itibaren etkisini iyice hissettiren küreselleşmenin, ahlak üzerinde önemli negatif etkilerinin olduğu tartışılmaktadır. Ahlaki değerin yitirilmesi günümüz dünyasının en önemli sorunlarından birisidir. Özellikle gençler arasında görülen şiddet, cinayet, alkol ve uyuşturucu bağımlılı̆̆ı gibi sorunlara ek olarak bu dönemde yaşanan ruhsal bunalımlar ve intiharlar bireysel nitelikli olmaktan çıkmış toplumsal hatta küresel ölçekte problemlere dönüşmüştür. Ahlaki değer sorunu ve şiddet sorunlarının çözümü için ülkeler sağlık ve sosyal politikaları üzerinde düzenlemeler yapmakta her geçen gün artan oranda ekonomik kaynak ayırmak durumunda kalmaktadırlar. $\mathrm{Bu}$ tür toplumsal nitelikli sorunlar büyük oranda gençler arasında görülmektedir. $\mathrm{Bu}$ nedenle problemlerin çözümü sadece ekonomik ya da sosyal politikalarla değil, eğitim politikaları ile de ciddi şekilde iliş̧ilidir. Gençler bu sorunların çoğunu ergenlik döneminde yaşadığ 1 için ilgili dönemde verilecek olan ahlak eğitimi, doğru sosyalleşme, fiziksel aktivitelere teşvik, şiddete karşı davranışlar büyük önem taşımaktadır (Turan, 2013:273).

Okulda şiddete yönelen gençlerin büyük bir kısmı, şiddete başvurmanın kendilerini ve ailelerini tehditlerden korumak için gerekli olduğunu düşünmektedirler. Bu görüşe sahip gençler sık sık kavgalara karışmakta, silah taşımakta, akranlarını ve öğretmenlerini tehdit edebilmektedirler (Everett ve Price, 1995; Malek ve ark., 1998). Ancak önemli bir sorun, gençlerin şiddet içeren davranışlar sergilemelerine rağmen kendilerini zorba olarak görmemeleridir (Quinn ve ark., 2007). Bu durum, şiddetin içselleşerek, hayatın bir parçası olarak görülmesine neden olmakta kişilerin şiddete yönelme eğilimini, şiddetin uygulandığı durumlara karşı tepkisizliği artırmaktadır.

$\mathrm{Bu}$ çalışma, şiddet olaylarının 15- 18 yaş grubu arasında yüksek seviyelere ulaşması ve bu yaş grubunun risk faktörü oluşturması nedeniyle, lise öğrencilerinin eğitim gördüğü orta eğitim düzeyinde gerçekleştirilmiş, lise öğrencilerinin şiddetle karşılaşma ve şiddeti algılama durumlarını, şiddet eğilim düzeylerini ve bunu etkileyen faktörleri belirlemek amacıyla yapılmıştır.

\section{Literatür Taraması}

Okullarda şiddet olgusu dünya üzerinde pek çok ülkenin önemli sorunları arasındadır. Şiddet kavramına yönelik yurt dışı çalışmalar da, eğitim ortamlarında saldırganlık ve şiddetin artması sebebiyle okullarda şiddet kavramı yaygın olarak kullanılmaya başlanmıştır (http://www.schoolsafety.us/School-Crime-and-ViolenceStatistics).

Ulusal okul birliği tarafından, 700 okulun yer aldığ araştırmanın sonucunda okullarda şiddet eğiliminin büyük bir artış gösterdiği sonucuna ulaşılmıştır. Şiddete yönelik çalışmalarda, ABD’de 1986 yılından başlayarak 4 yıllık süre içinde okullarda 71 kişinin tabancayla öldürüldüğü, 201 kişinin ciddi biçimde yaralandığı, 242 kişinin tabanca kullanılarak rehin alındığı tespit edilmiştir (Pietzak ve Petersen, 1998:23-26).

ABD'de 1999-2000 yılları arasında bütün devlet okullarının yer aldığ 1 bir araştırmada, okulların \%71'nde en az bir defa şiddet yaşandığı, \%20'nde ise ciddi şiddet olaylarının yaşandığı belirlenmiştir. 2001 yılında yapılan bir çalışmada ise 12-18 yaş grubu gençler arasında hırsızlık, ateşli silah kullanma, zorbalık gibi 764.000 suç işlendiği belirtilmiştir (Miller ve Chandler, 2004:6).

Avrupa Konseyi'nin 2-4 Aralık 2002 tarihleri arasında düzenlediği "okullarda şiddetin önlenmesi ve şiddetle mücadele için yerel ortaklıklar" konulu konferansın da, okullarda şiddetin yeni bir olgu olmadığı, ancak son yıllarda özellikle okulların kendilerini ve toplumu etkileyen zorluk ve gerilimlerden uzak tutalamaması nedeniyle, şiddet olayında büyük değişimlerin yaşandığı vurgulanmıştır (Avrupa Konseyi, 2002).

Ülkemizde okullardaki şiddet olaylarıyla ilgili olarak yapılmış bazı araştırmalara göre:

Pişkin (2003) şiddete yönelik çalışmasında, çocukların \%35'inin zorbalığa uğradığını, hem zorbalığa uğrayan hem de zorbalık edenlerin oranının \% 30, sadece zorbalık edenlerin oranının $\% 6$ olduğunu belirtmiş, erkeklerde bu duruma daha fazla rastlandığını, zorbalığın \%34 ile fiziksel, \%29 sözel, \%21 dolaylı, \%11 eşyalara zarar verme biçiminde gerçekleştiği sonucuna ulaşmıştır.

Kapçı (2004) çalışmasında, ilköğretim öğrencilerinin zorbalığa maruz kalma türünün ve sıklığının depresyon, kayg1 ve benlik saygısı gibi değişkenlerle ilişkisini araştırmış, ilköğretim dördüncü ve beşinci sınıf öğrencilerinin \%40 oranında bedensel, sözel, duygusal ve cinsel zorbalığa maruz kaldıklarını ve zorbalığın demografik değişkenlerden çok psikolojik değişkenlerle ilişkili olduğu sonucuna ulaşmıştır.

Özcebe, Üner ve Çetik 2004 yılı çalışmalarında, Ankara'da 400 lise öğrencisi üzerinde yaptıkları araştırmada, öğrencilerin \%19,8'nin çakı, bıçak, kuru sıkı tabanca ve tabanca taşıdığını, öğrencilerin \%8,8'nin şiddet uyguladığını, \%16,1'nin şiddete maruz kaldığını, \%20,6'sının ise hem şiddete maruz kaldığını hem de şiddet uyguladığını, öğrencilerin en fazla fiziksel şiddet sonra da duygusal şiddet uyguladıkları sonucuna ulaşmışlardır.

Kızmaz (2006) çalışmasında, okullarda meydana gelen şiddet davranışlarına neden olan öncül risk faktörlerini, düşük düzeydeki akademik başarı, okula bağlılık oranının 
düşüklüğü, okul koşulları, çeteye katılmalar olarak ifade etmiştir.

Eke ve Ögel (2006) çalışmalarını, İstanbul'da lise öğrencileri üzerinde gerçekleştirmişler, öğrencilerin yarsının son bir yıl içinde en az bir kez fiziksel kavgada bulunduklarını, fiziksel kavga sonucu, yaralandığını belirtenlerin oranının \%15.4, başkasını yaralayanların oranı $\% 26.3$, bıçak, çak1 ya da benzeri kesici alet taşıyanların oranı \%22.6, ateşli silah taşıyanların oranı \%9.8 olduğunu; araştırmaya katılan öğrencilerin \%10'unun çete üyesi olduklarını belirtmişlerdir.

Yurtal ve Cenkseven (2006) çalışmalarında, ilköğretim okullarında erkek öğrencilerin daha fazla zorba davranışlara maruz kaldıklarını, zorbalığın en fazla okul bahçesinde yaşandığını ve zorbaca davranışlarda bulunanların daha çok erkek ve yaşça büyük öğrenciler olduklarını tespit etmişlerdir.

Sevim ve Ataş (2015) Sütçü İmam Üniversitesin de okuyan 994 kadın ve erkek öğrenci üzerinde yaptıkları çalışmada, kadın ve erkeklerin şiddet ile ilgili farklı görüşlere sahip oldukları, Erkeklerin kadınlara oranla, şiddete daha 1lımlı baktıkları, şiddeti haklı kılacak gerekçeler ortaya koydukları, özellikle kadına yönelik şiddetin kaynağını kadınlarda gördükleri, genel olarak; gençliğin büyük oranının şiddete karşı olumsuz yönde bir tutum içerisinde oldukları sonucuna ulaşmışlardır.

MEB 2016 raporunda, orta öğretim düzeyindeki öğrencilerin disiplin sorunlarının azaltılması için yapılması gereken en önemli şeyin, öğrencilerin sosyal, kültürel ve sportif etkinliklere daha fazla yönelmelerini sağlamak olduğunu, enerjisini bu tarz faydalı alanlara kanalize eden öğrencilerin daha az disiplin olayına karıştığı sonucuna ulaşılmıştır. Disiplin sorunlarının fazla yaşanmasında etkili bir diğer faktörün, okulun çevresel özellikleri olduğuna işaret edilen raporda, 'nispeten şehir dışında olan ve merkezdeki çarşı, kafe ve diş etkenlere açık yerlerden uzak okullarda daha az disiplin sorunları yaşandığı be nedenle okulların merkezden uzak alanlarda konumlandırılmasının bir çözüm olabileceği' değerlendirmesinde bulunulmuştur (MEB, 2016).

Okullarda özellikle de liselerde meydana gelen şiddet olaylarının diğer ülkelerde olduğu gibi ülkemizde de son yıllarda artış gösterdiği görülmektedir. Okullarda görülen şiddet olaylarının hem eğitim-öğretim etkinliğinin hem de geniş bir çerçevede bireyin ruh sağlığını olumsuz yönde etkileyeceği dikkate alındığında, önleyici çalışmalara ihtiyacımız olduğu düşünülmektedir.

\section{Araștırmanın Amacı ve Önemi}

Şiddet olaylarının okullarda giderek artması ve alınan önlemlerin disiplin kurallarının dışına çıkamaması, son yıllarda farklı düzeylerde ve türdeki şiddet olayları toplumun genelini kaygılandıracak boyuta ulaşmıştır. Okullarda yaşanan şiddetin, öğrencinin yaşam kalitesini ve başarı düzeyini etkilemesi göz ardı edilemeyecek kadar önemlidir. Eğitim, toplumsal değişme ve dönüşümün temelini oluşturmaktadır. Şiddet olgusu ise bu durumu engelleyen etmenlerin başında yer almaktadır. Bu nedenle, şiddetin önlenmesine yönelik kalıcı önlemlerin alınması gerekmektedir. Bu gerekçelerden hareketle, araştırma lise öğrencilerinin şiddetle karşılaşma ve şiddeti algılama durumlarını, şiddet eğilim nedenlerini ve bunu etkileyen faktörleri belirlemek amacıyla yapılmıştır. Araştırma, gerekli izinler alındıktan sonra, Elazı̆̆ merkez ilçede bulunan devlet ve özel nitelikteki 42 liseye uygulanmış, liselerde okuyan öğrencilerle $(n=1032)$ gönüllük ilkesi gereğince yürütülmüştür.

\subsection{Anket Uygulamas1}

Veri toplama aracı olarak literatür araştırması sonucu geliştirilen bir adet anket kullanılmıştır. Anket formu 2 kısım ve 53 sorudan oluşmaktadır. Birinci bölümdeki 21 soru demografik nitelikte,bireyi ve okul ortamını tanımaya yöneliktir. İkinci bölüme yönelik sorular öğrencilerin okul içinde davranışları, öğretmenler ve idarenin tutumları, çevrenin durumunu, ailenin davranışını tespit etmeye yönelik likert ölçeğinde düzenlenmiş 32 sorudan oluşmaktadır. Soruların cevaplanması için likert ölçeği 1 "Hiç bir zaman", 2 "Çok nadir", 3" Ara sıra", 4 "Sik sık", 5 "Her zaman” şeklinde kodlanmıştır.

\subsection{Veri Girişi}

Araştırmada veri toplama aracı olarak anket formu kullanılmıştır. Anketin uygulaması sonucunda elde edilen veriler SPSS 22 (Statistical Packages For The Social Sciences) paket programında tanımlayıcı ve çıkarımsal olarak değerlendirilmiştir.

\section{Bulgular ve Değerlendirme}

$\mathrm{Bu}$ araştırmada, elde edilen veriler, tanımlayıcı istatistik, bağımsız örneklem $\mathrm{T}$ Testi ve Anova Testi kullanılarak analiz edilmiştir.

Analizler sonucunda, Elazı̆̆ il merkezinde özel ve devlet liselerinde öğrenim gören öğrencilerin lise türü farkı olmaksızın şiddet kavramını literatürdeki şekliyle bilmedikleri, en çok sözel şiddeti yaşadıkları ancak birçoğu tarafından şiddet algısı olarak fiziksel şiddettin ifade edildiği daha sonra cinsel şiddet ve ekonomik şiddetin şiddet olarak algılandığı tespit edilmiştir. Lise öğrencilerinin sözel şiddete çok s1k maruz kalmaları nedeniyle alışkanlık kazandıkları ve artık şiddet olarak görmedikleri, daha sert, daha ağır, yaralayııı ve hatta öldürücü boyuttaki eylemleri şiddet olarak algıladıkları tespit edilmiştir. Şiddetin yaygınlaşmasında medyanın, çevrenin, yoksulluğun ve göçün diğer faktörlere göre daha etkili olduğu sonucuna ulaşılmıştır. Çalışmanın sonuçları şiddet olaylarının sıklıkla, gençler arasında özellikle de okullarda yaşandığını doğrulamakta, şiddet olayında aile ilişkilerinin önem kazandığını sevgisiz ve baskıcı bir ortamda yetişen ve şiddet yaşayan çocukların psiko-sosyal gelişimlerinin olumsuz etkilenerek ileriki yıllarda toplumda birer şiddet uygulayıcı olabileceklerini kanıtlamaktadır. Gençlerin toplumsallaşmasında ailesinden sonra en önemli ortam okullardır. Bu nedenle şiddete müdahalede okullar da önem kazanmaktadır.

\subsection{Güvenilirlik Analizi}

Güvenilirlik analizi; daha önceden belirlenmiş bir ölçek türüne göre hazırlanmış ankete verilen yanıtların tutarlılığını ölçmektedir. Ölçek türü ordinal veya aralıklı olabilmekte ancak nominal ölçek bu analizlerde 
kullanılamamaktadır. Likert ölçeklerin de olduğu gibi hiçbir zaman(1) her zaman (5) tarzı sıralanabilir yanıtlar için güvenilirlik analizi uygulanmaktadır. Bu analiz, soruların birbirleri ile yakınlıklarının derecesini ortaya koymak için yapılmaktadır. $\mathrm{Bu}$ analizi yaparken bizim için önemli noktalardan birisi Cronbach's Alpha değeridir. Bu değer;

$\bullet 0.00<\mathrm{a}<0.40$ ise ölçek güvenilir değil

$\bullet 0.40<\mathrm{a}<0.60$ ise ölçek düşük güvenilirlikte

$\bullet 0.60<\mathrm{a}<0.80$ ise ölçek oldukça güvenilir

$\bullet 0.80<\mathrm{a}<1.00$ ise ölçek yüksek güvenilirlikte olarak değerlendirilmektedir.

Çalışmada kolaylık olması için, likert ölçekli üç grup soru için kısaltmalar kullanılmıştır. Öğrencilerin kişilik özelliklerine ait 15 adet soru için KİS kısaltması, öğrencilerin okul içerisinde karşılaştığı tavır ve davranışlar için LİS ve öğrencilerinin aile içerisinde karşılaştıkları tavır ve davranışlar için AİS kısaltmaları tercih edilmiştir. Çalışmada anketin likert ölçeği sorularına güvenilirlik analizi uygulanmış ve sonuçlar Tablo-1 de verilmiştir.

Tablo-1: Güvenilirlik Analizi

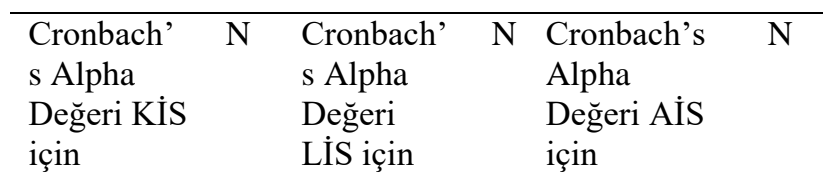

\begin{tabular}{llllll}
\hline, 673 & 15 &, 681 & 8 &, 632 & 9 \\
\hline
\end{tabular}

Tablo-1 incelendiğinde öğrencilerin kişilik özellikleri ile ilgili 15 adet soru için (KİS) yapılan güvenilirlik analizin de; Cronbach's Alpha değerinin; ,673 çıktığı, öğrencilerin okul içerisinde karşılaştıkları davranışlara ait 8 soru için (LIS) Cronbach's Alpha değerinin; ,681 ve öğrencilerin ailelerinin tutum ve davranışlarına ilişkin sorulara ait (AİS) Cronbach's Alpha değerinin; ,632 olduğu sonucuna ulaşılmıştır. Verilere ait Güvenilirlik Analizi sonuçları, yukarıda ifade edilen değerlerden $0.60<\mathrm{a}<0.80$ arasında değer aldıkları için ölçeğin yüksek güvenilirlikte olduğunu söyleyebiliriz.

\subsection{T Testi ve ANOVA Testi Analiz Sonuçları}

Çalışmamızda, yukarıda yer alan ilkeler ve amaçlar doğrultusunda bilimsel araştırmalar incelenmiş ve anket soruları öğrencilerin kişilik özelliklerini yansıtacak şekilde, lise ve aile ortamında karşılaştı̆̆ı tutum ve davranışları belirlemeye yönelik olarak hazırlanmış, öğrencilerin şiddet hakkındaki düşüncelerini belirlemek amaçlanmıştır. Bu doğrultuda 21 adet demografik değişken, kişiliğe yönelik 15 soru, lise ortamına yönelik 8 soru ve aile içi ortama yönelik 9 soru hipotezlerle sınanmıştır.

\subsubsection{T Testi Analiz Sonuçları}

Bağımsız iki örneklem T testi, iki örneklem grubu arasında ortalamalar açısından fark olup olmadığını araştırmak amacıyla kullanılmaktadır. İki grubun üyeleri birbirinden farklıdır ve gruplar arasında aynı özelliğe sahip üye bulunmaması gerekmektedir. $\mathrm{T}$ testi, bir gruptaki ortalamanın diğer gruptaki ortalamadan önemli derecede farklı olup olmadığını belirler. T testi için alternatif hipotezi aşağıdaki gibidir:
Ho: Öğrencilere ait kişisel özelliklerin bağımsız değişken cinsiyet grupları arasında anlamlı bir farklılık yoktur.

H1: Öğrencilere ait kişisel özelliklerin bağımsız değişken cinsiyet grupları arasında anlamlı bir farklılık vardır.

Çalışmada; KİS, LİS VE AİS likert ölçekli sorular tek tek ve ortalamaları alınarak t testi için cinsiyet, şiddete uğrayıp uğramadığı, lise türü ve silah ya da kesici alet taşıyıp taşımadığına göre karşılaştırılmış aralarında anlamlı bir fark olup olmadığı tespit edilmeye çalışılmıştır. Ölçeklerin ortalamaları, çalışmada uygulayacağımız testleri yaparken soruların genel ortalamalarını alarak diğer sorularla karşılaştırma yapmamızı sağlamaktadır. Tablo-2 de cinsiyet ile KIS T testi sonuçları yer almaktadır.

Tablo-2. Cinsiyet ile KİS ilişkisi T Testi Sonuçları

\begin{tabular}{|c|c|c|c|c|}
\hline Sorular & Cinsiyet & $\mathbf{N}$ & $\mathbf{X}$ & $\begin{array}{l}\text { T testi P } \\
\text { değerleri }\end{array}$ \\
\hline \multirow{2}{*}{$\begin{array}{l}\text { Arkadaşlarım çok } \\
\text { tartışmacı } \\
\text { olduğumu söylerler }\end{array}$} & Kız & 540 & 2,0056 &, 010 \\
\hline & Erkek & 490 & 2,1918 & ,010 \\
\hline \multirow[t]{2}{*}{ Birden sinirlenirim } & Kız & 540 & 3,2185 &, 161 \\
\hline & Erkek & 490 & 3,3306 &, 161 \\
\hline \multirow{2}{*}{$\begin{array}{l}\text { Biri çok üzerime } \\
\text { geldiğinde ona } \\
\text { vurabilirim }\end{array}$} & $\mathbf{K I z}$ & 540 & 2,5259 & ,000 \\
\hline & Erkek & 490 & 3,3000 & ,000 \\
\hline \multirow{2}{*}{$\begin{array}{l}\text { Hayatın bana } \\
\text { adaletli } \\
\text { davranmadığını } \\
\text { düşünüyorum }\end{array}$} & $\mathbf{K} \mathbf{z z}$ & 540 & 2,9630 &, 257 \\
\hline & Erkek & 490 & 3,0755 &, 258 \\
\hline \multirow{2}{*}{$\begin{array}{l}\text { Tanıdığım insanları } \\
\text { tehdit ettiğim } \\
\text { olmuştur }\end{array}$} & $\mathbf{K} \mathbf{}$ & 540 & 1,7185 &, 000 \\
\hline & Erkek & 490 & 1,9959 &, 000 \\
\hline \multirow[t]{2}{*}{ Sakin biriyim } & Kız & 540 & 3,2222 &, 295 \\
\hline & Erkek & 490 & 3,1306 &, 295 \\
\hline \multirow{2}{*}{$\begin{array}{l}\text { İnsanların yüzüne } \\
\text { gerçek fikirlerimi } \\
\text { söylerim }\end{array}$} & $\mathbf{K u z}$ & 540 & 4,0074 & ,900 \\
\hline & Erkek & 490 & 3,9918 & ,904 \\
\hline \multirow{2}{*}{$\begin{array}{l}\text { Genelde k1skanç } \\
\text { biriyim }\end{array}$} & $\mathbf{K} \mathbf{z z}$ & 540 & 3,0556 &, 016 \\
\hline & Erkek & 490 & 2,8224 &, 016 \\
\hline \multirow{2}{*}{$\begin{array}{l}\text { Haklarımı korumak } \\
\text { için şiddete } \\
\text { başvururum }\end{array}$} & $\mathbf{K u z}$ & 540 & 1,8296 &, 000 \\
\hline & Erkek & 490 & 2,5408 &, 000 \\
\hline \multirow{2}{*}{$\begin{array}{l}\text { Yabanc1lara } \\
\text { güvenmem }\end{array}$} & Kız & 540 & 2,6593 &, 078 \\
\hline & Erkek & 490 & 2,8490 &, 078 \\
\hline \multirow{2}{*}{$\begin{array}{l}\text { İnsanlar bana nazik } \\
\text { davranırsa ne } \\
\text { isteyecek diye } \\
\text { merak ederim }\end{array}$} & $\mathbf{K} \mathbf{}$ & 540 & 3,0944 &, 842 \\
\hline & Erkek & 490 & 3,1122 &, 842 \\
\hline
\end{tabular}




\begin{tabular}{|c|c|c|c|c|}
\hline \multirow{2}{*}{$\begin{array}{l}\text { İstediğimi elde } \\
\text { edemediğimde } \\
\text { kızgınlığımı } \\
\text { gösteririm }\end{array}$} & Kız & 540 & 2,8000 & ,790 \\
\hline & Erkek & 490 & 2,7776 &, 790 \\
\hline \multirow{2}{*}{$\begin{array}{l}\text { Bir çok insandan } \\
\text { daha çok kavga } \\
\text { ederim }\end{array}$} & Kız & 540 & 1,7296 & ,000 \\
\hline & Erkek & 490 & 2,1041 & ,000 \\
\hline \multirow{2}{*}{$\begin{array}{l}\text { Beni rahatsiz } \\
\text { edenlere surarak, } \\
\text { tepki vermeyerek } \\
\text { ilgilenmem. }\end{array}$} & Kız & 540 & 2,8037 & ,461 \\
\hline & Erkek & 490 & 2,8694 & ,461 \\
\hline \multirow{2}{*}{$\begin{array}{l}\text { Arkadaşlarımla } \\
\text { aynı fikirde } \\
\text { değilsem açıkça } \\
\text { söylerim }\end{array}$} & Kız & 540 & 4,2148 & ,319 \\
\hline & Erkek & 490 & 4,1429 & ,320 \\
\hline \multirow[t]{2}{*}{ KİS_ort } & Kız & 540 & 2,7899 & ,000 \\
\hline & Erkek & 490 & 2,9490 & ,000 \\
\hline
\end{tabular}

Cinsiyet grupları ile KİS soruları arasında istatistiksel açıdan anlamlı bir ilişki olup olmadığı bağımsız örneklem T testi ile belirlenmiştir. Tablo-2' de KİS sorularının ortalamalarını ifade eden KİS_ort için p değerinin, Kız öğrenciler için 0,00 ; Erkek öğrenciler için 0,00 olduğu, $p$ değerlerinin 0,05 'den küçük olduğu için cinsiyet ile KIIS_ort arasında anlamlı bir farklılığın olduğu sonucuna ulaşılmıştır. Tek tek sorulara bakıldığında; Arkadaşlarım çok tartışmacı olduğumu söylerler $(, 010)$,Biri çok üzerime geldiğinde ona vurabilirim (,000), Tanıdığım insanları tehdit ettiğim olmuştur $(, 000)$, Genelde kıskanç biriyim $(, 016)$, Haklarımı korumak için şiddete başvururum $(, 000)$, Birçok insandan daha çok kavga ederim $(, 000)$ ifadelerinde p değerleri 0,05 değerinden küçük olduğu için Ho hipotezi red edilmekte ve aralarında anlamlı bir farklılık olduğu sonucuna ulaşılmaktadır. Diğer ifadeler de p değeri 0,05 den büyük olduğu için Ho hipotezi kabul edilmektedir.

Tablo-2 de likert ölçeği ortalamalarını veren $\mathrm{X}$ değerlerine bakıldığında Arkadaşlarım çok tartışmacı olduğumu söyler ifadesine kız erkek ayrımı olmadan çok nadir cevabını verdikleri, Birden sinirlenirim ifadesine yine cinsiyet fark1 olmaksızın ara sıra cevabını verdikleri, İnsanların yüzüne gerçek fikirlerimi söylerim, Arkadaşlarımla aynı fikirde değilsem açıkça söylerim ifadelerine sık sık şeklinde cevap verdikleri, Haklarımı korumak için şiddete başvururum, Tanıdığım insanları tehdit ettiğim olmuştur, Birçok insandan daha çok kavga ederim gibi şiddet içiren ifadelere cinsiyet ayrımı olmaksızın çok nadir şeklinde cevap verdikleri, KIS_ort baktığımızda ise, genel olarak ifadelerin ara sıra şeklinde yorumladıkları sonucuna ulaşılmıştır.

Lisede şiddete uğruyor musunuz evet hayır grupları ile KİS soruları arasında ilişkiyi belirmek için $t$ testi yapılmış sonuçlar tablo-3 de verilmiştir.
Tablo-3: Lisede Şiddet ile KİS ilișkisi T Testi Sonuçları

\begin{tabular}{|c|c|c|c|c|}
\hline Sorular & $\begin{array}{l}\text { Lisede } \\
\text { şiddet }\end{array}$ & $\mathbf{N}$ & $\mathbf{X}$ & $\begin{array}{l}T \text { testi } P \\
\text { değerleri }\end{array}$ \\
\hline \multirow{2}{*}{$\begin{array}{l}\text { Arkadaşlarım çok } \\
\text { tartışmacı olduğumu } \\
\text { söylerler }\end{array}$} & Evet & 168 & 2,3095 & ,008 \\
\hline & Hayır & 864 & 2,0532 & ,019 \\
\hline \multirow[t]{2}{*}{ Birden sinirlenirim } & Evet & 168 & 3,4881 &, 017 \\
\hline & Hayır & 864 & 3,2303 & 016 \\
\hline \multirow{2}{*}{$\begin{array}{l}\text { Biri çok üzerime } \\
\text { geldiğinde ona } \\
\text { vurabilirim }\end{array}$} & Evet & 168 & 3,2679 &, 000 \\
\hline & Hayır & 864 & 2,8264 &, 000 \\
\hline \multirow{2}{*}{$\begin{array}{l}\text { Hayatın bana adaletli } \\
\text { davranmadığını } \\
\text { düşünüyorum }\end{array}$} & Evet & 168 & 3,4643 & ,000 \\
\hline & Hayır & 864 & 2,9317 &, 000 \\
\hline \multirow{2}{*}{$\begin{array}{l}\text { Tanıdığım insanları } \\
\text { tehdit ettiğim } \\
\text { olmuştur }\end{array}$} & Evet & 168 & 2,1190 &, 002 \\
\hline & Hayır & 864 & 1,7986 & ,008 \\
\hline \multirow[t]{2}{*}{ Sakin biriyim } & Evet & 168 & 3,0238 &, 121 \\
\hline & Hayır & 864 & 3,2072 & ,133 \\
\hline \multirow{2}{*}{$\begin{array}{l}\text { İnsanların yüzüne } \\
\text { gerçek fikirlerimi } \\
\text { söylerim }\end{array}$} & Evet & 168 & 3,9226 &, 578 \\
\hline & Hayır & 864 & 4,0162 &, 458 \\
\hline \multirow{2}{*}{$\begin{array}{l}\text { Genelde kıskanç } \\
\text { biriyim }\end{array}$} & Evet & 168 & 3,0060 & ,601 \\
\hline & Hayır & 864 & 2,9375 & ,601 \\
\hline \multirow{2}{*}{$\begin{array}{l}\text { Haklarımı korumak } \\
\text { için şiddete } \\
\text { başvururum }\end{array}$} & Evet & 168 & 2,5357 &, 000 \\
\hline & Hayır & 864 & 2,0984 &, 000 \\
\hline \multirow{2}{*}{$\begin{array}{l}\text { Yabancilara } \\
\text { güvenmem }\end{array}$} & Evet & 168 & 3,0476 &, 015 \\
\hline & Hayır & 864 & 2,6921 & ,017 \\
\hline \multirow{2}{*}{$\begin{array}{l}\text { İnsanlar bana nazik } \\
\text { davranırsa ne } \\
\text { isteyecek diye merak } \\
\text { ederim }\end{array}$} & Evet & 168 & 3,2202 &, 247 \\
\hline & Hayır & 864 & 3,0810 &, 254 \\
\hline \multirow{2}{*}{$\begin{array}{l}\text { İstediğimi elde } \\
\text { edemediğimde } \\
\text { kızgınlığımı } \\
\text { gösteririm }\end{array}$} & Evet & 168 & 3,0298 &, 013 \\
\hline & Hayır & 864 & 2,7454 &, 016 \\
\hline \multirow{2}{*}{$\begin{array}{l}\text { Bir çok insandan } \\
\text { daha çok kavga } \\
\text { ederim }\end{array}$} & Evet & 168 & 2,3750 &, 000 \\
\hline & Hayır & 864 & 1,8171 &, 000 \\
\hline \multirow{2}{*}{$\begin{array}{l}\text { Beni rahatsiz } \\
\text { edenlere surarak, } \\
\text { tepki vermeyerek } \\
\text { ilgilenmem. }\end{array}$} & Evet & 168 & 2,8929 &, 555 \\
\hline & Hayır & 864 & 2,8218 &, 568 \\
\hline
\end{tabular}




\begin{tabular}{lllll}
\hline $\begin{array}{l}\text { Arkadaşlarımla aynı } \\
\text { fikirde değilsem } \\
\text { açıkça söylerim }\end{array}$ & Evet & 168 & 4,0179 &, 044 \\
\cline { 2 - 5 } & Hayır & 864 & 4,2141 &, 072 \\
\hline KİS_ort & Evet & 168 & 3,0480 &, 000 \\
\cline { 2 - 5 } & Hayır & 864 & 2,8314 &, 000 \\
\hline
\end{tabular}

Lisede şiddete uğruyor musunuz evet hayır grupları ile KİS soruları arasında istatistiksel açıdan anlamlı bir ilişki olup olmadığı bağımsız örneklem $\mathrm{T}$ testi ile belirlenmiştir. Tablo-2' de KIS sorularının ortalamalarını ifade eden KİS_ort için $\mathrm{p}$ değerinin, 0,00 olduğu ve $\mathrm{p}$ değerlerinin $0,05^{\prime}$ den küçük olduğu için, lisede şiddet ile KİS_ort arasında anlamlı bir farklılığın olduğu sonucuna ulaşılmıştır. Tek tek sorulara bakıldı̆̆ında; Arkadaşlarım çok tartışmacı olduğumu söylerler (,010), Biri çok üzerime geldiğinde ona vurabilirim $(, 000)$, Tanıdığım insanları tehdit ettiğim olmuştur $(, 000)$, Genelde kıskanç biriyim $(, 016)$, Haklarımı korumak için şiddete başvururum $(, 000)$, Bir çok insandan daha çok kavga ederim $(, 000)$ ifadelerinde p değerleri 0,05 değerinden küçük olduğu için Ho hipotezi red edilmekte ve aralarında anlamlı bir farklılık olduğu sonucuna ulaşılmaktadır. Diğer ifadeler için $p$ değeri 0,05 den büyük olduğu için Ho hipotezi kabul edilmektedir. Arkadaşlarım çok tartışmacı olduğumu söylerler, Birden sinirlenirim, Biri çok üzerime geldiğinde ona vurabilirim, Hayatın bana adaletli davranmadığını düşünüyorum, Tanıdığım insanları tehdit ettiğim olmuştur,Haklarımı korumak için şiddete başvururum, İstediğimi elde edemediğimde kızgınlığımı gösteririm, Bir çok insandan daha çok kavga ederim ifadelerinin p değerleri ,000 ile,005 arasında değerler aldıkları ve, 005 değerinden küçük olduğu için aralarında anlamlı bir farklılık olduğu sonucuna ulaşılmış yani $\mathrm{H} 1$ hipotezi kabul edilmiştir.

\subsubsection{ANOVA Analizi}

Varyans analizi iki ya da daha fazla gruba ait ortalamalar arasındaki farkın anlamlı olup olmadığı ile ilgili hipotezleri test etmek için kullanılmaktadır. Eğer ikiden fazla grubun ortalamaları karşılaştırılacak ise $\mathrm{F}$ Testi diğer bir ismiyle Varyans Analizi (ANOVA) uygulanmaktadır. İkiden fazla grubun ortalamaları arasında anlamlı bir farklılık olup olmadığını test eden ANOVA analizinin alternatif hipotezleri aşağıdaki gibidir.

HA1:Ailenin geliri ile KİS arasında anlamlı bir farklılık vardir.

HA2:Ailenin geliri ile LíSarasında anlamlı bir farklılık vardır.

HA3:Ailenin geliri ile AİSarasında anlamlı bir farklılık vardir.

Hipotezler ortalama değişkenler ve tek tek sorular ile demografik değişkenlerin $p$ değerlerine göre yorumlanmıştır. Eğer $\mathrm{p}$ değeri 0,05 den küçük ise HA hipotezi kabul edilmekte değişkenler arasında anlamlı farklılıkların olduğu şeklinde yorumlanmaktadır, $\mathrm{p}$ değeri 0,05 den büyük ise HA reddedilmektedir.

Çalışmada, aile geliri KİS, LİS, AİS gibi bağımlı değişkenler hem tek tek soru olarak hem de ortalaması alınarak ilişkilendirilmiş, $p$ değerleri 0,05 den küçük

bulunmuş ve HA kabul edilerek aralarında anlamlı bir fark olduğu sonucuna ulaşılmıştır. Aşağıda bu değişkenlere ait değerler tablo da verilmiş ve yorumlanmıştır. Tablo-4 de Aile geliri ile KİS soruları arasındaki ilişkinin ANOVA analizi sonuçları yer almaktadır.Tablo-4 de ankete katılan öğrencilerin aile gelirleri ile KİS_ort ve 'Biri çok üzerime geldiğinde ona vurabilirim, Tanıdığım insanları tehdit ettiğim olmuştur, Sakin biriyim, Haklarımı korumak için şiddete başvururum, İstediğimi elde edemediğimde kızgınlığımı gösteririm, Birçok insandan daha çok kavga ederim' ifadelerinde $p$ değeri 0,05 'den küçük olduğu için aralarında anlamlı bir farklılık olduğu sonucuna ulaşılmıştır. Varyans analizi, karşılaştırılan grupların hangileri arasında fark olduğunu bildiremez. Bu nedenle anlamlı fark bulunduğu zaman bu farkın hangi gruplar arasındaki farktan kaynaklandığını bulmak amacıyla PostHoc testi ile karşılaştırmaların yapılması gerekmektedir. Post-Hoc testlerinde birçok seçenek bulunmaktadır. Hepsinin temel işlevi aynıdır. Çok sayıda Post-Hoc teknik bulunmaktadır ve hangisinin kullanılacağına karar verilirken belirleyici öncelik varyansların homojenliğidir. Varyansların homojen bulunmasına veya bulunmamasına bağlı olarak farklı teknikler tercih edilmektedir. Gruplar arasında fark var ise; varyansların homojenliği testi tablosundaki $\mathrm{p}$ (anlamlılık(sig)) değeri incelenir, $\mathrm{p}>0,05$ ise varyanslar homojen dağılmıştır, $\mathrm{p}<0,05$ ise varyanslar homojen dağılmamıştır yorumu yapılır.

Varyanslar homojen dağılmışsa, genellikle Tukey testi tercih edilmektedir. Varyanslar homojen dağılmamışsa genellikle Tamhane's T2 testleri Post- Hoc testleri olarak belirlenmektedir. Tablo-12 de Post-Hoc testi için yapılan homojenlik testi sonuçları; $\mathrm{p}=0,05$ karşılaştırmak için hesaplandığın da, $065 ;, 329 ;, 203 ;, 540 ;, 070 ;, 645 ;, 925$; ,163;,117; ,056; 687; 607; ,016;,958;,849;,403 gibi 0,05 'den büyük sonuçlar elde edilmiştir.

Bu nedenle Post Hoc için Tukey testi tercih edilmiş, test sonuçları Post Hoc sütununda verilmiştir. Tablo-4 de Post Hoc sütununda; Aile geliri; Çok düşük (1), Düşük (2), Orta (3), Yüksek (4), Çok yüksek (5) şeklinde numaralandırılmış ve her grubun ikişerli karşılaştırmaları yapılarak karşılaştırılan grupların ortalamaları arasındaki farklar numaralarla ilişkilendirilerek $\mathrm{p}$ değeri olarak verilmiştir. Tablo-4 de Post-Hoc sütununda Kís_ort göre $1-2=00 ; 2$ $1=00 ; 3-1=00 ; 4-1=, 02$ ve $5-2=, 04$ çok düşük gelir düşük gelir, orta gelir çok düşük gelir, yüksek gelir çok düşük gelir ve çok yüksek gelir düşük gelir arasında $p$ değerleri 0,05 den küçük olduğu için ortalamaları arasında anlamlı bir farklılık olduğu sonucuna ulaşılmıştır.

Tablo-5 de ankete katılan öğrencilerin aile gelirleri ile Anne veya babamla sıkıntılarımı, sorunlarımı paylaşırım ifadesi dışındaki tüm ifadelerde $\mathrm{p}$ değeri 0,05 'den küçük olduğu için aralarında anlamlı bir farklılık olduğu sonucuna ulaşılmıştır. Varyans analizi, karşılaştırılan grupların hangileri arasında fark olduğunu belirleyemediği için bu farkın hangi gruplar arasındaki farktan kaynaklandığını bulmak amaciyla Post-Hoc testi uygulanmış, Post-Hoc testi için yapılan homojenlik testi sonuçları; $\mathrm{p}=0,05$ karşılaştırmak için hesaplandığın da ,026,000,000,004 ,024,013,011,020,014,000 gibi 0,05'den küçük sonuçlar elde edilmiştir. Varyanslar homojen dağılmadığı için Tamhane's T2 testleri Post- Hoc testi olarak belirlenmiş test sonuçları Post Hoc sütununda verilmiştir. 
Tablo-5 de Post-Hoc Annem veya babam hata yaptığım zaman beni azarlarlar ifadesine göre; $1-2=, 020 ; 2-1=, 020$ ve 3-1=,006 çok düşük gelir düşük gelir, düşük gelir ile çok düşük gelir, orta gelir ile çok düşük gelir arasında $p$ değerleri 0,05 den küçük olduğu için ortalamaları arasında anlamlı bir farklılık olduğu, annem veya babam işleri yoğun olduğu için benimle az ilgilenirler ifadesine göre; $1-4=, 002$; 2-4=,004; 3-4=,011; 4-3=,011 çok düşük gelir yüksek gelir, düşük gelir ile yüksek gelir, orta gelir ile yüksek gelir, yüksek gelir ile orta gelir arasında $p$ değerleri 0,05 den küçük olduğu için ortalamaları arasında anlamlı bir farklılık olduğu sonucuna ulaşılmıştır.

Tablo-6 da ankete katılan öğrencilerin aile gelirleri ile okula gidip gelirken tanımadığım kişilerin bana kötülük yapmalarından korkarım ifadesi dışındaki tüm ifadelerde $\mathrm{p}$ değeri 0,05 'den küçük olduğu için aralarında anlamlı bir farklılık olduğu sonucuna ulaşılmıştır. Gruplar arasındaki farkın, hangi gruplar arasındaki farktan kaynaklandığını bulmak amaciyla Post-Hoc testi uygulanmış, Post-Hoc testi için yapılan homojenlik testi sonuçları; $\mathrm{p}=0,05$ karşılaştırmak için hesaplandığın da, ,002,; ,038; ,007; ,047; ,014; ,000; ,040; ,000; ,016 gibi 0,05'den küçük sonuçlar elde edilmiştir. Varyanslar homojen dağılmadığı için Tamhane's T2 testleri Post- Hoc testi olarak belirlenmiş test sonuçları Post Hoc sütununda verilmiştir.

Tablo-6 de Post-Hoc Okulda, bazı öğretmen veya idareciler bana sözlü şiddet uygularlar ifadesine göre; $1-2=, 001 ; 2$ $5=, 041 ; 3-1=, 002 ; 4-1=, 014 ; 5-2=, 041$, çok düşük gelir ile düşük gelir, düşük gelir ile çok yüksek gelir, orta gelir ile çok düşük gelir, yüksek gelir ile çok düşük gelir, çok yüksek gelir ile düşük gelir arasında p değerleri 0,05 den küçük olduğu için ortalamaları arasında anlamlı bir farklılık olduğu, Öğretmenim, sınıfımızdaki öğrenciler arasında ayrım yapar ifadesine göre; $1-2=, 032 ; 4-1=, 016$ çok düşük gelir ile düşük gelir, yüksek gelir ile çok düşük gelir, arasında p değerleri 0,05 den küçük olduğu için ortalamaları arasında anlamlı bir farklılık olduğu, Hata yaptığım zaman öğretmenim bana fiziksel şiddet uygular ifadesine göre, 1 $2=, 002 ; 3-1=, 004 ; 4-1=, 006$ çok düşük gelir ile düşük gelir, orta gelir ile çok düşük gelir, yüksek gelir ile çok düşük gelir, arasında p değerleri 0,05 den küçük olduğu için ortalamaları arasında anlamlı bir farklılık olduğu, Okul çevresinde uyuşturucu madde, sigara, hap vs. satanlar vardır ifadesine göre, $1-2=, 021 ; 3-1=, 017 ; 4-1=, 028$ çok düşük gelir ile düşük gelir, orta gelir ile çok düşük gelir, yüksek gelir ile çok düşük gelir, arasında p değerleri 0,05 den küçük olduğu için ortalamaları arasında anlamlı bir farklılık olduğu, Okul çevresinde yolumuzu kesip harçlıklarımızı bizden zorla alan kişi veya gruplar bulunmaktadır ifadesine göre; 2-5=,012; 3-5=,013; 4-5=,029 düşük gelir ile çok yüksek gelir, orta gelir ile çok yüksek gelir, yüksek gelir ile çok yüksek gelir, arasında p değerleri 0,05 den küçük olduğu için ortalamaları arasında anlamlı bir farklılık olduğu, LİS_ort göre; $1-2=, 001 ; 2-5=, 007 ; 3-5=, 024 ; 4$ $5=, 034$ düşük gelir ile düşük gelir, düşük gelir ile çok yüksek gelir, orta gelir ile çok yüksek gelir, yüksek gelir ile çok yüksek gelir arasında p değerleri 0,05 den küçük olduğu için ortalamaları arasında anlamlı bir farklılık olduğu sonucuna ulaşılmıştır.

Tablo-4:Aile Geliri İle KİS Soruları ANOVA analizi

\begin{tabular}{|c|c|c|c|c|c|}
\hline & & $\mathrm{N}$ & $\mathrm{X}$ & $\mathrm{P}$ & Post Hoc \\
\hline \multirow[t]{6}{*}{ Arkadaşlarım çok tartışmacı olduğumu söyler. } & Çok Düşük(1) & 17 & 2,588 & \multirow{6}{*}{,067 } & \\
\hline & Düşük (2) & 269 & 2,000 & & \\
\hline & Orta(3) & 561 & 2,078 & & \\
\hline & Yüksek(4) & 166 & 2,210 & & \\
\hline & Çok Yüksek(5) & 19 & 2,473 & & \\
\hline & Total & 1032 & 2,095 & & \\
\hline \multirow[t]{5}{*}{ Birden sinirlenirim. } & Çok Düşük(1) & 17 & 3,764 & \multirow{5}{*}{, 060} & \\
\hline & Düşük (2) & 269 & 3,171 & & \\
\hline & $\operatorname{Orta}(3)$ & 561 & 3,251 & & \\
\hline & Yüksek(4) & 166 & 3,397 & & \\
\hline & Çok Yüksek(5) & 19 & 3,789 & & \\
\hline \multirow{5}{*}{ Biri çok üzerime geldiğinde ona vurabilirim. } & Çok Düşük(1) & 17 & 3,588 & \multirow{5}{*}{,003 } & \\
\hline & Düşük (2) & 269 & 2,888 & & $2-5=, 09$ \\
\hline & $\operatorname{Orta}(3)$ & 561 & 2,869 & & $3-5=, 03$ \\
\hline & Yüksek(4) & 166 & 2,813 & & $4-5=, 05$ \\
\hline & Çok Yüksek(5) & 19 & 4,000 & & \\
\hline \multirow{5}{*}{$\begin{array}{l}\text { Hayatın bana adaletli davranmadığını } \\
\text { düşünüyorum. }\end{array}$} & Çok Düşük(1) & 17 & 3,882 & \multirow{5}{*}{,067 } & \\
\hline & Düşük (2) & 269 & 2,981 & & \\
\hline & $\operatorname{Orta}(3)$ & 561 & 3,044 & & \\
\hline & Yüksek(4) & 166 & 2,849 & & \\
\hline & Çok Yüksek(5) & 19 & 3,473 & & \\
\hline \multirow{5}{*}{ Tanıdığım insanları tehdit ettiğim olmuştur } & Çok Düşük(1) & 17 & 2,294 & \multirow{5}{*}{,004 } & \\
\hline & Düşük (2) & 269 & 1,806 & & $2-5=, 03$ \\
\hline & $\operatorname{Orta}(3)$ & 561 & 1,802 & & $3-5=, 05$ \\
\hline & Yüksek(4) & 166 & 1,933 & & $4-5=, 03$ \\
\hline & Çok Yüksek(5) & 19 & 2,789 & & \\
\hline \multirow[b]{2}{*}{ Sakin biriyim } & Çok Düşük(1) & 17 & 2,176 & \multirow[b]{2}{*}{,008 } & $1-3=, 02$ \\
\hline & Düşük (2) & 269 & 3,115 & & $1-4=, 01$ \\
\hline
\end{tabular}




\begin{tabular}{|c|c|c|c|c|c|}
\hline & Orta(3) & 561 & 3,224 & & $3-1=, 02$ \\
\hline & Yüksek(4) & 166 & 3,283 & & $4-1=, 01$ \\
\hline & Çok Yüksek(5) & 19 & 2,631 & & \\
\hline \multirow[t]{5}{*}{ İnsanların yüzüne gerçek fikirlerimi söylerim } & Çok Düşük(1) & 17 & 3,941 & \multirow{5}{*}{,946 } & \\
\hline & Düşük (2) & 269 & 3,962 & & \\
\hline & $\operatorname{Orta}(3)$ & 561 & 4,048 & & \\
\hline & Yüksek(4) & 166 & 3,921 & & \\
\hline & Çok Yüksek(5) & 19 & 3,894 & & \\
\hline \multirow{5}{*}{ Genelde kıskanç biriyim } & Çok Düşük(1) & 17 & 3,529 & \multirow{5}{*}{,211 } & \\
\hline & Düşük (2) & 269 & 2,799 & & \\
\hline & Orta(3) & 561 & 2,967 & & \\
\hline & Yüksek(4) & 166 & 3,060 & & \\
\hline & Çok Yüksek(5) & 19 & 3,000 & & \\
\hline \multirow{5}{*}{ Haklarımı korumak için şiddete başvururum } & Çok Düşük(1) & 17 & 3,117 & \multirow{5}{*}{,001 } & $1-2=, 02$ \\
\hline & Düşük (2) & 269 & 2,111 & & $2-5=, 03$ \\
\hline & Orta(3) & 561 & 2,158 & & $3-5=, 02$ \\
\hline & Yüksek(4) & 166 & 2,096 & & $4-1=, 02$ \\
\hline & Çok Yüksek(5) & 19 & 3,105 & & $5-4=, 01$ \\
\hline \multirow[t]{5}{*}{ Yabancılara güvenmem } & Çok Düşük(1) & 17 & 3,470 & \multirow{5}{*}{, 248} & \\
\hline & Düşük (2) & 269 & 2,706 & & \\
\hline & $\operatorname{Orta}(3)$ & 561 & 2,803 & & \\
\hline & Yüksek(4) & 166 & 2,590 & & \\
\hline & Çok Yüksek(5) & 19 & 2,526 & & \\
\hline \multirow{5}{*}{$\begin{array}{l}\text { İnsanlar bana nazik davranırsa ne isteyecek diye } \\
\text { merak ederim }\end{array}$} & Çok Düşük(1) & 17 & 3,705 & \multirow{5}{*}{, 287} & \\
\hline & Düşük (2) & 269 & 3,037 & & \\
\hline & Orta(3) & 561 & 3,114 & & \\
\hline & Yüksek(4) & 166 & 3,072 & & \\
\hline & Çok Yüksek(5) & 19 & 3,473 & & \\
\hline \multirow{5}{*}{$\begin{array}{l}\text { İstediğimi elde edemediğimde kıggınlığımı } \\
\text { gösteririm }\end{array}$} & Çok Düşük(1) & 17 & 3,882 & \multirow{5}{*}{, 010} & $1-2=, 00$ \\
\hline & Düşük (2) & 269 & 2,750 & & $2-1=, 00$ \\
\hline & Orta(3) & 561 & 2,764 & & $3-1=, 02$ \\
\hline & Yüksek(4) & 166 & 2,789 & & $4-1=, 01$ \\
\hline & Çok Yüksek(5) & 19 & 3,210 & & \\
\hline \multirow{5}{*}{ Bir çok insandan daha çok kavga ederim } & Çok Düşük(1) & 17 & 2,823 & \multirow{5}{*}{,003 } & $1-2=, 01$ \\
\hline & Düşük (2) & 269 & 1,869 & & $2-1=, 01$ \\
\hline & $\operatorname{Orta}(3)$ & 561 & 1,898 & & $3-1=, 04$ \\
\hline & Yüksek(4) & 166 & 1,831 & & $4-1=, 01$ \\
\hline & Çok Yüksek(5) & 19 & 2,578 & & \\
\hline \multirow{5}{*}{$\begin{array}{l}\text { Beni rahatsız edenlere surarak, tepki vermeyerek } \\
\text { ilgilenmem. }\end{array}$} & Çok Düşük(1) & 17 & 2,352 & \multirow{5}{*}{,715 } & \\
\hline & Düşük (2) & 269 & 2,832 & & \\
\hline & $\operatorname{Orta}(3)$ & 561 & 2,836 & & \\
\hline & Yüksek(4) & 166 & 2,879 & & \\
\hline & Çok Yüksek(5) & 19 & 2,789 & & \\
\hline \multirow{5}{*}{$\begin{array}{l}\text { Arkadaşlarımla aynı fikirde değilsem açıkça } \\
\text { söylerim }\end{array}$} & Çok Düşük(1) & 17 & 4,294 & \multirow{5}{*}{,929 } & \\
\hline & Düşük (2) & 269 & 4,137 & & \\
\hline & Orta(3) & 561 & 4,206 & & \\
\hline & Yüksek(4) & 166 & 4,162 & & \\
\hline & Çok Yüksek(5) & 19 & 4,157 & & \\
\hline \multirow[t]{5}{*}{ KİS_ort } & Çok Düşük(1) & 17 & 3,294 & \multirow{5}{*}{, 001} & $1-2=, 00$ \\
\hline & Düşük (2) & 269 & 2,811 & & $2-1=, 00$ \\
\hline & Orta(3) & 561 & 2,871 & & $3-1=, 02$ \\
\hline & Yüksek(4) & 166 & 2,859 & & $4-1=, 02$ \\
\hline & Çok Yüksek(5) & 19 & 3,193 & & $5-2=, 04$ \\
\hline
\end{tabular}

Tablo-5: Aile Geliri İle AİS Soruları ANOVA Analizi

\begin{tabular}{llllll}
\hline & & $\mathrm{N}$ & $\mathrm{X}$ & $\mathrm{P}$ & Post Hoc \\
\hline $\begin{array}{lllll}\text { Evde annem ve babam birbirleriyle } \\
\text { bağırarak konuşurlar }\end{array}$ & Çok Düşük(1) & 17 & 2,5294 & \multirow{2}{*}{022} & \\
\cline { 2 - 4 } & Düşük (2) & 269 & 1,8699 & & \\
\cline { 2 - 4 } & Orta(3) & 561 & 1,7629 & \\
\hline
\end{tabular}




\begin{tabular}{|c|c|c|c|c|c|}
\hline & Yüksek(4) & 166 & 1,8133 & & \\
\hline & Çok Yüksek(5) & 19 & 2,1053 & & \\
\hline & Total & 1032 & 1,8178 & & \\
\hline \multirow{5}{*}{$\begin{array}{l}\text { Babam çok sinirlendiğinde anneme fiziksel } \\
\text { şiddet uygular }\end{array}$} & Çok Düşük(1) & 17 & 2,4118 & \multirow[t]{5}{*}{022} & \\
\hline & Düşük (2) & 269 & 1,6729 & & \\
\hline & Orta(3) & 561 & 1,6738 & & \\
\hline & Yüksek(4) & 166 & 1,7470 & & \\
\hline & Çok Yüksek(5) & 19 & 2,0000 & & \\
\hline \multirow{5}{*}{$\begin{array}{l}\text { Annem çok sinirlendiğinde babama fiziksel } \\
\text { şiddet uygular }\end{array}$} & Çok Düşük(1) & 17 & 2,3529 & \multirow[t]{5}{*}{,000 } & \\
\hline & Düşük (2) & 269 & 1,5762 & & \\
\hline & Orta(3) & 561 & 1,5187 & & \\
\hline & Yüksek(4) & 166 & 1,5060 & & \\
\hline & Çok Yüksek(5) & 19 & 2,2105 & & \\
\hline \multirow{5}{*}{$\begin{array}{l}\text { Annem veya babam hata yaptığım zaman } \\
\text { beni azarlarlar. }\end{array}$} & Çok Düşük(1) & 17 & 3,8824 & \multirow[t]{5}{*}{,000 } & $1-2=, 020$ \\
\hline & Düşük (2) & 269 & 2,5056 & & $2-1=, 020$ \\
\hline & Orta(3) & 561 & 2,4492 & & $3-1=, 006$ \\
\hline & Yüksek(4) & 166 & 2,2892 & & \\
\hline & Çok Yüksek(5) & 19 & 2,6842 & & \\
\hline \multirow{5}{*}{$\begin{array}{l}\text { Annem veya babam işleri yoğun olduğu için } \\
\text { benimle az ilgilenirler. }\end{array}$} & Çok Düşük(1) & 17 & 2,8824 & \multirow{5}{*}{,002 } & $1-4=, 002$ \\
\hline & Düşük (2) & 269 & 2,0818 & & $2-4=, 004$ \\
\hline & Orta(3) & 561 & 1,9394 & & $3-4=, 011$ \\
\hline & Yüksek(4) & 166 & 1,8434 & & $4-3=, 011$ \\
\hline & Çok Yüksek(5) & 19 & 2,4737 & & \\
\hline \multirow{10}{*}{$\begin{array}{l}\text { Annem veya babam (işleri yoğun olmasına } \\
\text { rağmen) ihtiyacım olduğunda ödevlerime } \\
\text { yardımcı olurlar }\end{array}$} & Çok Düşük(1) & 17 & 2,0588 & \multirow[t]{5}{*}{,001 } & \\
\hline & Düşük (2) & 269 & 2,6691 & & \\
\hline & Orta(3) & 561 & 2,8057 & & \\
\hline & Yüksek(4) & 166 & 3,2530 & & \\
\hline & Çok Yüksek(5) & 19 & 2,9474 & & \\
\hline & Çok Düşük(1) & 17 & 2,6471 & \multirow[t]{5}{*}{,081 } & \\
\hline & Düşük (2) & 269 & 3,1264 & & \\
\hline & Orta(3) & 561 & 3,1747 & & \\
\hline & Yüksek(4) & 166 & 3,4639 & & \\
\hline & Çok Yüksek(5) & 19 & 3,4737 & & \\
\hline \multirow{5}{*}{$\begin{array}{l}\text { Anne veya babamla sıkıntılarımı, } \\
\text { sorunlarımı paylaşırım }\end{array}$} & Çok Düşük(1) & 17 & 3,0000 & \multirow{5}{*}{, 136} & \\
\hline & Düşük (2) & 269 & 3,1822 & & \\
\hline & Orta(3) & 561 & 3,0463 & & \\
\hline & Yüksek(4) & 166 & 3,2289 & & \\
\hline & Çok Yüksek(5) & 19 & 3,7895 & & \\
\hline \multirow{5}{*}{ Evde istediğim kadar TV izleyebilirim } & Çok Düşük(1) & 17 & 2,7059 & \multirow[t]{5}{*}{,034 } & \\
\hline & Düşük (2) & 269 & 2,0223 & & \\
\hline & Orta(3) & 561 & 2,0374 & & \\
\hline & Yüksek(4) & 166 & 2,0482 & & \\
\hline & Çok Yüksek(5) & 19 & 2,8421 & & \\
\hline \multirow[t]{5}{*}{ AİS_ort } & Çok Düşük(1) & 17 & 2,7190 & \multirow[t]{5}{*}{, 000} & \\
\hline & Düşük (2) & 269 & 2,3007 & & \\
\hline & Orta(3) & 561 & 2,2676 & & \\
\hline & Yüksek(4) & 166 & 2,3548 & & \\
\hline & Çok Yüksek(5) & 19 & 2,7251 & & \\
\hline
\end{tabular}

Tablo-6: Aile Geliri İle Lís Soruları ANOVA Analizi

\begin{tabular}{|c|c|c|c|c|c|}
\hline & & $\mathrm{N}$ & $\mathrm{X}$ & $P$ & Post Hoc \\
\hline \multirow{6}{*}{$\begin{array}{l}\text { Okulda, arkadaşlarım veya diğer öğrenciler } \\
\text { tarafindan sözlü şiddete uğrarım }\end{array}$} & Çok Düşük(1) & 17 & 3,4765 & \multirow[t]{6}{*}{,034 } & \\
\hline & Düşük (2) & 269 & 3,2335 & & \\
\hline & $\operatorname{Orta}(3)$ & 561 & 2,1872 & & \\
\hline & Yüksek(4) & 166 & 2,2048 & & \\
\hline & Çok Yüksek(5) & 19 & 2,4737 & & \\
\hline & Total & 1032 & 2,1550 & & \\
\hline \multirow{2}{*}{$\begin{array}{l}\text { Okulda, bazı öğretmen veya idareciler bana } \\
\text { sözlü şiddet uygularlar. }\end{array}$} & Çok Düşük(1) & 17 & 3,2941 & \multirow[b]{2}{*}{, 000} & $1-2=, 001$ \\
\hline & Düşük (2) & 269 & 2,0149 & & $2-5=, 041$ \\
\hline
\end{tabular}




\begin{tabular}{|c|c|c|c|c|c|}
\hline & $\operatorname{Orta}(3)$ & 561 & 2,0624 & & $3-1=, 002$ \\
\hline & Yüksek(4) & 166 & 2,2289 & & $4-1=, 014$ \\
\hline & Çok Yüksek(5) & 19 & 2,8947 & & $5-2=, 041$ \\
\hline \multirow{5}{*}{ Öğretmenim, beni notla tehdit eder. } & Çok Düşük(1) & 17 & 3,1765 & \multirow{5}{*}{, 034} & \\
\hline & Düşük (2) & 269 & 2,3717 & & \\
\hline & $\operatorname{Orta}(3)$ & 561 & 2,3850 & & \\
\hline & Yüksek(4) & 166 & 2,4759 & & \\
\hline & Çok Yüksek(5) & 19 & 3,2105 & & \\
\hline \multirow{5}{*}{$\begin{array}{l}\text { Öğretmenim, sınıfımızdaki öğrenciler } \\
\text { arasında ayrım yapar }\end{array}$} & Çok Düşük(1) & 17 & 3,5882 & \multirow{5}{*}{,006 } & $1-2=, 032$ \\
\hline & Düşük (2) & 269 & 2,5056 & & \\
\hline & $\operatorname{Orta}(3)$ & 561 & 2,6595 & & \\
\hline & Yüksek(4) & 166 & 2,3976 & & $4-1=, 016$ \\
\hline & Çok Yüksek(5) & 19 & 3,1053 & & \\
\hline \multirow{5}{*}{$\begin{array}{l}\text { Hata yaptığım zaman öğretmenim bana } \\
\text { fiziksel şiddet uygular. }\end{array}$} & Çok Düşük(1) & 17 & 3,0588 & \multirow{5}{*}{, 000} & $1-2=, 002$ \\
\hline & Düşük (2) & 269 & 1,8364 & & \\
\hline & Orta(3) & 561 & 1,9305 & & $3-1=, 004$ \\
\hline & Yüksek(4) & 166 & 1,9157 & & $4-1=, 006$ \\
\hline & Çok Yüksek(5) & 19 & 2,6842 & & \\
\hline \multirow{5}{*}{$\begin{array}{l}\text { Okul çevresinde uyuşturucu madde, sigara, } \\
\text { hap vs. satanlar vardır }\end{array}$} & Çok Düşük(1) & 17 & 3,2353 & \multirow[t]{5}{*}{,025 } & $1-2=, 021$ \\
\hline & Düşük (2) & 269 & 2,1450 & & \\
\hline & $\operatorname{Orta}(3)$ & 561 & 2,1426 & & $3-1=, 017$ \\
\hline & Yüksek(4) & 166 & 2,1627 & & $4-1=, 028$ \\
\hline & Çok Yüksek(5) & 19 & 2,5789 & & \\
\hline \multirow{5}{*}{$\begin{array}{l}\text { Okul çevresinde yolumuzu kesip } \\
\text { harçlıklarımızı bizden zorla alan kişi veya } \\
\text { gruplar bulunmaktadır }\end{array}$} & Çok Düşük(1) & 17 & 1,8235 & \multirow{5}{*}{,033 } & \\
\hline & Düşük (2) & 269 & 1,7695 & & $2-5=, 012$ \\
\hline & Orta(3) & 561 & 1,7897 & & $3-5=, 013$ \\
\hline & Yüksek(4) & 166 & 1,8313 & & $4-5=, 029$ \\
\hline & Çok Yüksek(5) & 19 & 2,6842 & & \\
\hline \multirow{5}{*}{$\begin{array}{l}\text { Okula gidip gelirken tanımadığım kişilerin } \\
\text { bana kötülük yapmalarından korkarım }\end{array}$} & Çok Düşük(1) & 17 & 2,1176 & \multirow{5}{*}{, 076} & \\
\hline & Düşük (2) & 269 & 1,9405 & & \\
\hline & Orta(3) & 561 & 2,0463 & & \\
\hline & Yüksek(4) & 166 & 2,0000 & & \\
\hline & Çok Yüksek(5) & 19 & 1,7895 & & \\
\hline \multirow[t]{5}{*}{ LİS_ort } & Çok Düşük(1) & 17 & 2,8088 & \multirow[t]{5}{*}{, 000} & $1-2=, 001$ \\
\hline & Düşük (2) & 269 & 2,0771 & & $2-5=, 007$ \\
\hline & $\operatorname{Orta}(3)$ & 561 & 2,1504 & & $3-5=, 024$ \\
\hline & Yüksek(4) & 166 & 2,1521 & & $4-5=, 034$ \\
\hline & Çok Yüksek(5) & 19 & 2,6776 & & \\
\hline
\end{tabular}

\section{Sonuç}

Genç nesil, psikolojik yapıları güçlendirilerek korunması ve kollanması gereken en kıymetli varlıklarımızdır. Gençliğimizi şiddet içeren davranışlardan ve şiddet ortamlarından uzaklaştırmak herkesin en önemli görevidir. Son yıllarda yapılan araştırmalar Dünya genelinde olduğu gibi Türkiye de de ortaöğretim öğrencileri arasında şiddet içeren faaliyetlerin artığını göstermektedir. Madde kullanım yaygınlığı, fiziksel ve cinsel şiddet olayları bölgelere göre değişmekle birlikte genel olarak artış göstermektedir. $\mathrm{Bu}$ nedenle risk faktörlerinin belirlenmesi, koruyucu önlemlerin alınması açısından önem kazanmaktadır.

Araştırmaya katılan öğrencilerin çoğu, yaşamlarında şiddetin var olduğunu ve bunu sıklıkla arkadaş ve okul ortamında yaşadıklarını belirtirken, şiddeti daha çok "dayak ve kavga" olarak fiziksel boyutuyla tanımlamışlardır. Ağız dalaşı, lâf atma, alay etme, öğretmenlerin kızması vb. davranışları daha az derecede şiddet olarak algılamakta hatta şiddet olarak değerlendirmemektedirler.
Hızlı sosyal değişme sürecinde toplumlarda bireye değişen ve gelişen rolleri öğretmede kitle iletişim araçları sıklıkla kullanılmaktadır. Bu ortamlarda internet ağlarının yaygın bir şekilde kullanılması verilmek istenen mesajların kolayca paylaşılmasını sağlamaktadır. Medyada haber olarak verilen şiddet ve sapma eylemleri gerçek bir durumu yansitırken diğer yandan eyleme maruz kalmamış izleyicilere şiddet içerikli görseller sunmak fiilen şiddetin uygulanması anlamına da gelmektedir şeklinde literatür de ifade edilen durum çalışmada; öğrencilerin büyük çoğunluğunu şiddeti futbol maçları, medya, arkadaş ve okul ortamında gözlemlediklerini ifade etmeleri ile desteklenmektedir.

Literatürde yer alan birçok yıllar öncesine ait ya da daha güncel çalışmalarda şiddet kavramının; ekonomik, sosyal ailevi boyutlarından bahsedilmektedir. Çalışmada, öğrencilerin şiddet yaşama konusunda risk grubu oluşturduğu, cinsiyetin, sınıfın, özellikle babanın ve annenin işsiz olmasının, aile içi davranışın, ekonomik durumun, şiddet eğiliminde etkili faktörler olduğu belirlenmiştir. Bu sonuç literatürü desteklemektedir. 
Şiddet sorununun önemli özelliklerinden biri, kuşaktan kuşağa aktarılmasıdır.Şiddet uygulayan yetişkinlerin büyük bölümünde çocuklukta aile içi şiddete maruz kalma öyküsü saptanmaktadır. Öğrencilerin bazılarının şiddetin şiddetle önlenebileceği görüşünde olmaları be nedene bağlı olabileceği düşünülmektedir ve şiddet döngüsünün kırılması için müdahale edilmesi gereken bir nokta olarak görülmektedir.

Gençlerin öğrenim gördüğü okullarda şiddet nedenleri arasında boş zaman değerlendirme olanaklarının yetersizliği, kız arkadaş sorunu, yaşa özgü risk alma davranışları, yoksulluk, okul sevgisinin düşük düzeyde olması, disiplin cezalarının caydırıcı olmaması, öğretmen ilgisizliği, bilinçlendirici ve farkındalık yaratıcı eğitimlerin verilmemesi, sosyal aktivite yetersizliği şiddetin artmasının başlıca etkenleri olarak belirlenmiştir.

KİS soruları arasında şiddet içerikli olanlara genellikle çok düşük ve düşük gelir grubundakilerin sık sık şeklinde cevap vermeleri hem çevresel olarak hem de ekonomik etkenlerin gençler üzerinde etkili olduğunu göstermektedir. Yine lisede şiddet olaylarını sık sık yaşayan ve yaşatan grubun çok düşük ve düşük gelir grubundaki öğrencilerden oluşması şiddetin ekonomik etkisinin sadece aile içi ya da çevreyle sınırlı olmadığını okul içeresinde de etkisini gösterdiğini kanıtlamaktadır.

Gençler eğlenmek, sosyal ve duygusal gereksinimlerini gidermek, sorunlarından uzaklaşmak, heyecan aramak gibi çok değişik nedenlerle madde kullanmayı deneyebilirler. Gençlerin sigara, alkol ve uyuşturucu madde kullanımına zemin hazırlayan çok sayıda risk etkeni tanımlanmaktadır. Bunlardan biri aile ve gencin geliridir. Çalışmada, yüksek ve çok yüksek gelire sahip ailelerin çocukları ise, okul içi ve okul dışı ortamlarda farklı tehlikeler ve farklı şiddet türleri ile karşılaşmaktadır sonucuna ulaşılmıştır. En büyük tehdit uyuşturucu vb. yasadışı ürünleri satan kişilerin hedeflerine girmelerine, geliri yüksek ailelerin çocuklarının harçlıklarının da yüksek olacağı beklentisi bu gruptaki öğrencilerin riskli grup olmalarına neden olmaktadır. Ayrıca tehdit küfür alay etme gibi sözel şiddet olaylarını ve dayak gibi fiziki şiddet olaylarına maruz kalmalarına da yol açmaktadır. Düşük ve yüksek gelir grubundaki gençlerin öğrencilerin her ikisi de farklı şiddet olayları ile karşı karşıyadır. Ekonomik durum şiddeti kesinlikle olumsuz olarak etkilemektedir. Düşük gelir grubundaki öğrenciler çevresel faktörlerle şiddete alışık ve meyilli olmaktadırlar.

Şiddetin yaygınlaşarak devam etmesi, toplum bireylerinde çeşitli sağlık sorunlarına ve toplumun sosyal yapısında aksaklıklara neden olarak, toplumun geleceğinin sağlam temellere dayanmasını engelleyeceği bu çalışma ve diğer çalışmalarla desteklenmiştir. Gençlerin sağlığa ve bedene zararlı davranışlar geliştirmemesi, olumlu sosyal ilişkiler kurarak psiko-sosyal gelişimlerini sürdürmesi gereksinimi vardır ve bunun sağlanması büyük önem taşımaktadır. Bu nedenle, bu ve bir çok çalışmadan elden edilen sonuçlar baz alınarak özellikle okul ortamında çocuklara iyi vakit geçirecekleri sosyal faaliyetlerin sağlanması, toplumdaki tehlike ve tehditlere karşı aile ve öğrencilerin konferans vb. ile bilinçlendirilmesi, şiddet eğilimi yüksek öğrencilerle özel olarak ilgilenilmesinin gerekli olduğu düşünülmektedir. Öğrencilerin dışarıdaki tehlikelere maruz kalmayacakları şekilde evlerine ulaşmalarının sağlanması, çok düşük gelir grubunda yer alan gençlerin eğitimlerine devam etmeleri ve şiddetten uzak durmaları için özel ve devlet bursları ile desteklenmeleri, kötü çevre faktörlerini engellemeye yönelik olarak yatılı okul sayısının artırılmasının acil alınması gereken önlemler arasında olduğu düşünülmektedir.

Şiddet konusunda ailelere büyük sorumluluklar düştüğünden, çocuklarına aynı duyarlılık ve istekle, ekonomik ve psikolojik yönden destek olmalı, bu ilgi ve yardımı ailesinden bulamayan gençlerimize bulunduğu kurumun-okulun destek verebilmesi şiddetin önlenmesi için gerekli görülmektedir.

\section{Kaynakça}

Avc1, R. Ve Güçray, S. S. (2010). Şiddet davranış1 gösteren ve göstermeyen ergenlerin ailelerinin aile işlevleri, aile bireylerine ilişkin problemler, öfke ve öfke ifade tarzları açısından incelenmesi. Kuram ve Uygulamada Eğitim Bilimleri Dergisi, 10, 45-76.

Avrupa Konseyi. (2002). Okullarda şiddetin önlenmesi ve şiddetle mücadele için yerel ortaklıklar. Konferans Sonunda Kabul Edilen Sonuç Bildirgesi, Fransa, 2-4, Aralik.

Birimoğlu, C. (2012). Gaziantep Üniversitesinin Eğitim Fakültesi Öğrencilerinin Şiddete Bakış Açıları.

Chase KA., O' Leary K. D, Heyman R E. (2001). Categorizing Partner-Violent Men Within The ReactiveProactive Typology Model, 69(3), 567-572.

Çakır, M. (2007). İslam Hukuku Açısından Şiddet Ve Terör Olgusu. Yayınlanmamış Yüksek Lisans Tezi, Çukurova Üniversitesi Sosyal Bilimler Enstitüsü, Adana.

Deveci, S. E., Acik, Y., \& Ayar, A. (2007). A Survey Of Rate Of Victimization And Attitudes Towards Physical Violence Among School-Aged Children İn Turkey. Child: Care, Health And Development, 34 (1), 25-31.

Eke, C. Y., Ve Ögel, K. (2006). İstanbul'daki Okullarda Suç Ve Şiddetin Yaygınlığı. I. Şiddet Ve Okul: Okul Ve Çevresinde Çocuğa Yönelik Şiddet Ve Alınabilecek Tedbirler Uluslararası Katılımlı Sempozyum Bildiri Özetleri. İstanbul: Duman Ofset, S.22.

Everett, S.,And Price, J. (1995). Students' Perceptions Of Violence İn The Public Schools: The Met Life Survey. Journal Of Adolescent Health, 17, 345-352.

Filiz,H. (2000). Cumhurbaşkanlığının Üniversite Sorunları Raporu, 26 Mart, Ankara.

Gelbal S. (2006). Okullarda Şiddetin Önlenmesi, Mevcut Uygulamalar Ve Sonuçları. Türk Eğitim Derneği Kitapçı̆̆ı. Ankara, 28-31.

Güney C. (2008). Şiddetin Bahanesi Olmaz. Tepe Yayınlar1, Ar1 Matbaası; İstanbul, 144-151.

Kapçı, E. G. (2004). İlköğretim Öğrencilerinin Zorbalığa Kalma Türünün Ve Sıklığının Depresyon, Kaygı Ve Benlik Saygısıyla İlişkisi. Ankara Üniversitesi Eğitim Bilimleri Fakültesi Dergisi, 37 (1), 1-13.

Kızmaz, Z. (2006). Okullardaki Şiddet Davranışının Kaynakları Üzerine Kuramsal Bir Yaklaşım, C.Ü. Sosyal Bilimler Dergisi, Mayıs, 30 (1), 47-70. 
Milli Eğitim Bakanlığı (MEB). (2016). Ortaöğretim İzleme ve Değerlendirme Raporu, http://www.meb.gov.tr/liselere-yonelik-degerlendirmeraporu-yayimlandi/haber/12227/tr, E.T: 03.01.2019.

Miller, A. K. and Chandler, K. (2004). Violence İn U. S. Public Schools. 2000 School Survey On Crime And Safety, National Center Of Education Statistics.

November, www.Apa.Org/Books/431639a.Html - 7k - E. $\mathrm{T}: 02.01 .2019$.

Özcebe, H., Üner, S. ve Çetik, H. (2006), Adolesanlarda Şiddet Davranışları (Üç Lise, Ankara, 2004). I. Şiddet Ve Okul: Okul Ve Çevresinde Çocuğa Yönelik Şiddet Ve Alınabilecek Tedbirler Uluslararası Katılımlı Sempozyum Bildiri Özetleri. İstanbul: Duman Ofset, S.27.

Özerkmen, N. (2012). Toplumsal Bir Olgu Olarak Şiddet. Akademik Bakış Dergisi, (28): 1-19.

Pietzak, D., Petersen, G. J. And Speaker, K. M. (1998). Perception Of School Violence By Elementary And Middle School. Professional School Counseling, 1(4), 23-29.

Pişkin, M. (2003). Okullarımızda Yaygın Bir Sorun: Akran Zorbalığı. VII. Ulusal Psikolojik Danışma Ve Rehberlik Kongresi Bildiri Özetleri, Ankara: Pegema Yayıncılık.

Roberts G. Response of Health Professionals to Domestic Violence in Emergency Departments, www.Aic.Gov.Au/Publications/Proceedings/27/Robert s.Pdf, E. T. 01.01.2019.

Sevim Y. ve Ataş S. (2015). Üniversite Gençlerinde Şiddet Eğilimliliği Ve Öğrencilerin Aile İçi Şiddete Bakış Açıları, Fırat Üniversitesi Sosyal Bilimler Dergisi, 25 (1),285-302.
Quinn, G., Bell-Ellison, B., Loomis, W., \& Tucci, M. (2007). Adolescent Perceptions Of Violence: Formative Research Findings From A Social Marketing Campaign To Reduce Violence Among Middle School Youth. Public Health, 121 (5), 357-366.

The National School Safety Center, http://www.Schoolsafety.Us/School-Crime-AndViolence-Statistics-P- 9.html, E.T: 03.08.2018.

Tuncay S. (2000). Türkiye'de Gençlik Sorunlarının Psikolojik Boyutu" Muğla Üniversitesi, SBE Dergisi, Güz, 1 (1).

Turan İ. (2013),Gençlik Döneminde Görülen Ahlaki Sorunlar Karşısında Din Kültürü Ve Ahlak Bilgisi Dersinin Yeri, Atatük Üniversitesi İlahiyat Fakültesi Dergisi, Say1: 40, 271-293.

U.S. Department Of Education. Crime, Violence, Discipline, And Safety İn U.S. Public Schools. Findings From The School Survey On Crime And Safety: 200506. Retrieved September 27, 2007. From Http://Nces.Ed.Gov/Pubsearch. Et: 08.10.2018.

Vahip I. (2002). Evdeki Şiddet Ve Gelişimsel Boyutu: Farklı Bir Açıdan Bakış, Türk Psikiyatri Dergisi, 13(4): 312-319.

Yarman, S. (2000). Cumhurbaşkanlığının Üniversite Sorunları Raporu, 26 Mart, Ankara.

Yurtal, F. ve Cenkseven, F. (2006). İlköğretim Okullarında Zorbalığın İncelenmesi. I. Şiddet Ve Okul: Okul Ve Çevresinde Çocuğa Yönelik Şiddet Ve Alınabilecek Tedbirler Uluslararası Katılımlı Sempozyum Bildiri Özetleri. İstanbul: Duman Ofset. 
